\title{
FULL-ENDOSCOPIC LUMBAR DISCECTOMY
}

\author{
DISCECTOMIA LOMBAR TOTALMENTE ENDOSCÓPICA
}

DISCECTOMÍA LUMBAR TOTALMENTE ENDOSCÓPICA

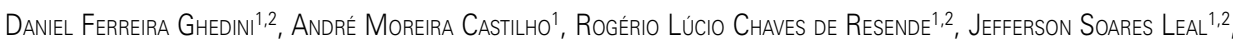 \\ Túlio Vinícius de Oliveira Campos'1, Marco Antônio Percope de Andrade ${ }^{1,2}$ \\ 1. Biocor Instituto, Belo Horizonte, MG, Brazil. \\ 2. Universidade Federal de Minas Gerais, Hospital das Clínicas, Orthopedics and Traumatology Service, Belo Horizonte, MG, Brazil.
}

\begin{abstract}
Objective: Retrospective study of the functional outcome of patients with lumbar disc herniation who underwent full-endoscopic discectomy. Methods: Fifteen consecutive patients, 10 men and 5 women, mean age of 34.2 years, were evaluated at 15, 30, 90 and 180 days after surgery through the Oswestry Disability Index (ODI) questionnaire and the Visual Analogue Scale (VAS) of axial and lower limbs pain. Results: There was a significant improvement in ODI evaluation of patients when comparing the preoperative results with the third and sixth postoperative month $(p<0.05)$, as well as the VAS for preoperative axial pain with respect to 15,30 and 90 days $(p<0.05)$ after surgery, and VAS for preoperative pain in the lower limbs with respect to 15, 90 and 180 days postoperatively $(p<0.05)$. Conclusion: The full-endoscopic discectomy is an effective procedure which should be considered as an alternative to conventional discectomy.
\end{abstract}

Keywords: Endoscopy; Hernia; Low back pain; Sciatica; Intervertebral disc.

\section{RESUMO}

Objetivo: Estudo retrospectivo do resultado funcional de pacientes com hérnia de disco lombar submetidos à discotomia totalmente endoscópica. Métodos: Quinze pacientes consecutivos, 10 homens e cinco mulheres, com média de idade de 34,2 anos, foram avaliados após 15, 30, 90 e 180 dias do pós-operatório por meio do questionário Oswestry Disability Index (ODI) e da Escala Analógica Visual (EVA) para dor axial e nos membros inferiores. Resultados: Houve significativa melhora funcional na avaliação do ODI dos pacientes comparando-se os resultados pré-operatórios com o terceiro e sexto mês de pós-operatório ( $p<0,05)$, bem como da EVA para dor axial pré-operatória com relação a 15, 30 e 90 dias $(p<0,05)$ de pós-operatório, e da EVA para dor em membro inferior pré-operatória com relação a 15, 90 e 180 dias de pós-operatório $(p<0,05)$. Conclusão: A discotomia totalmente endoscópica é um procedimento eficaz que deve ser considerado como uma das alternativas à discotomia convencional.

Descritores: Endoscopia; Hérnia; Dor lombar; Ciática; Disco intervertebral.

\section{RESUMEN}

Objetivo: Estudio retrospectivo de los resultados funcionales en pacientes con hernia de disco lumbar sometidos a la discectomía totalmente endoscópica. Métodos: Quince pacientes consecutivos, 10 hombres y 5 mujeres, con edad promedio de 34,2 años, fueron evaluados después de 15, 30, 90 y 180 días de la cirugía y respondieron el cuestionario Oswestry Disability Index (ODI) y la Escala Visual Analógica (EVA) para el dolor axial y de las extremidades inferiores. Resultados: Hubo una mejora significativa en la evaluación funcional del ODI de los pacientes al comparar los resultados preoperatorios con el tercer y sexto mes después de la cirugía $(p<0,05)$, así como la EVA para el dolor axial preoperatorio con respecto a 15, 30 y 90 días $(p<0,05)$ después de la cirugía y EVA para el dolor en el miembro inferior con respecto al preoperatorio y 15 , 90 y 180 días después de la intervención ( $p<0,05)$. Conclusión: La discectomía totalmente endoscópica es un procedimiento eficaz que debe ser considerado como una alternativa a la discectomía convencional.

Descriptores: Endoscopía; Hernia; Dolor de la región lumbar; Ciática; Disco intervertebral.

\section{INTRODUCTION}

Open discectomy is a surgical procedure that has been used for many years in the treatment of lumbar disc hernias. ${ }^{1}$

Percutaneous methods have been described since the early 1970 s. $^{2-6}$ One of these methods, the interlaminar microdiscectomy using a microscope, ${ }^{7,8}$ emerged at the end of the 1970s and gained attention due to its good results and low surgical trauma. Full endoscopic (FE) and transforaminal (TF) surgeries emerged at the end of the 1990s following the use of endoscopy in posterolateral approach surgeries. ${ }^{9-15}$

The good results of open microdiscectomy are already well-established in the literature. However, complications related to surgical trauma, such as epidural fibrosis and instability, may occur, being symptomatic in up to $10 \%$ of cases. ${ }^{16-17}$

Minimally invasive procedures have been used to minimize tissue damage. In several areas, endoscopy is already the standard treatment technique. In spine surgery, two techniques have been used more often - FE TF surgery ${ }^{18-22}$ and FE IL surgery. ${ }^{14,15}$

The TF technique has been shown to be effective in the excision of intra- or extraforaminal hernias, but is more difficult in the treatment of central herniations because of its lateral approach. ${ }^{13}$

The purpose of this study is to retrospectively evaluate the outcomes of patients with symptomatic lumbar disc herniations submitted to full endoscopic (transforaminal or interlaminar) treatment. 


\section{METHOD}

Fifteen patients with lumbosciatalgia refractory to conservative treatment (physiotherapy for more than six months, medication with anti-inflammatory agents and opioids, selective root block with corticosteroid injection) were included in the study. Of these, ten patients were male and five were female, with an average age of 34.2 years (ranging from 25 to 49 years of age). In the group of patients studied, 28 disc hernias were identified: one between L3-L4, 14 between L4-L5, and 13 between L5-S1. All the patients were treated surgically, six using the FE TF technique and nine using the FE IL technique. The procedures were all performed by the same surgeon. The patients were evaluated preoperatively using a questionnaire consisting of the Oswestry Disability Index (ODI) and the visual analog scale (VAS) for axial pain and for pain in the lower limbs (LL). The patients were monitored postoperatively at 15 days, 30 days, 90 days, and six months, using the same questionnaires mentioned above with the addition of four yes or no questions to be answered by them:

Since your endoscopic surgery, have you had any lumbar symptoms at the same level?

Are you satisfied with the outcome of your endoscopic surgery?

Would you undergo the same endoscopic surgery in the future or would you recommend it to someone you know based on your experience?

Did your spine or leg symptoms worsen after your surgery?

The questionnaires were filled out in outpatient visits to one of the study authors and the patient medical records were evaluated retrospectively. All patients consented to participate in the study by signing the Informed Consent Form.

Fifteen patients responded postoperatively to the questionnaire at fifteen days, eleven at 30 days, eight at ninety days, and six at six months. The patients were evaluated from May, 2011 to February, 2013. The patients signed the Informed Consent Form. The study was conducted with the approval of the Institutional Review Board as approval number 004/2013.

The FE TF technique is performed via an extreme lateral incision of $5 \mathrm{~mm}$ and the introduction of an atraumatic cannula. Following the introduction of the guide wire, the cannulated dilator is inserted and a beveled surgical sheath is introduced. Decompression is then performed under direct vision and continuous irrigation. The FE IL technique is performed in a similar way with the entry point at the lateral edge of the IL window through which the cannulated dilator advances until the yellow ligament is visualized. At this point, a space of $3-5 \mathrm{~mm}$ is created through the yellow ligament and decompression is performed under direct vision and continuous irrigation. (Figure 1)

The average procedural time was one hour and seventeen minutes (a minimum of 47 minutes and a maximum of 2 hours and 30 minutes). The longest surgical times occurred in the first cases, at the beginning of the learning curve. Bleeding was minimal and therefore not quantifiable. The patients were free to begin walking 6 hours following surgery and were discharged after an average of 12 hours (ranging from 6 to 24 hours).

The instrument used had optics of $6.9 \mathrm{~mm}$ containing a $4.2 \mathrm{~mm}$ eccentric intra-endoscopic working channel. (Figure 2) The external beveled sheath had a $7.9 \mathrm{~mm}$ diameter. All the instruments, including

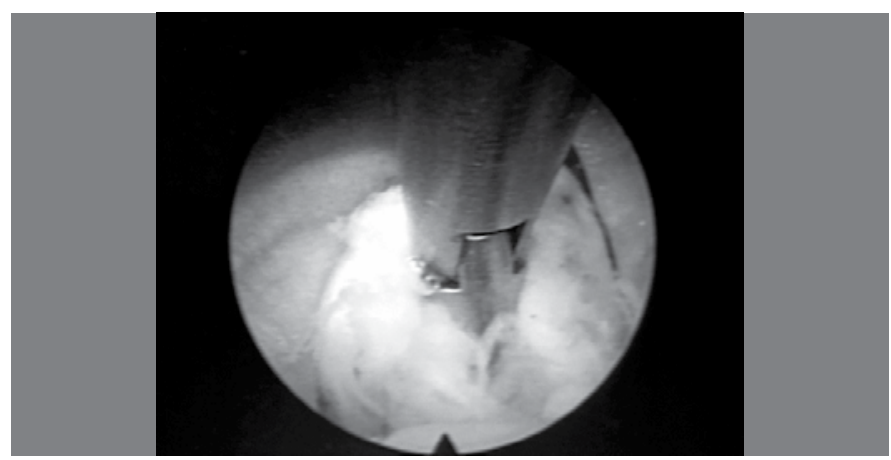

Figure 1. Intraoperative view at the moment of the resection of the extruded fragment.

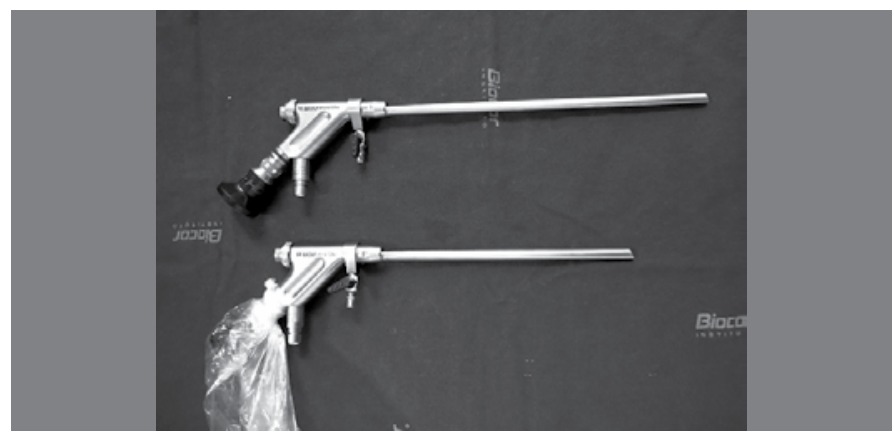

Figure 2. Endoscope for performing the FE TF (above) and the FE IL (below).

the endoscopy tower, were supplied by WOLF (Richard Wolf $\mathrm{GmbH}$, Knittlingen, Germany).

The Kruskal-Wallis test with comparisons by the Dunn method was used to perform the statistical analysis.

\section{RESULTS}

Tables 1, 2, and 3 display the general characteristics of the results of the ODI, VAS for axial pain, and VAS for pain in the LL in the groups studied. In terms of the ODI, only the comparisons between the preoperative group, averaging $46 \%$ (ranging from $15-100 \%$ ), and the three months group, averaging 13.5\% (ranging from 0-30\%), and the six months group, averaging $14.5 \%$ (ranging from 8-22\%), demonstrated statistically significant functional improvement in the patients in these timeframes. (Table 4)

The comparisons of the VAS for axial pain showed significance between the preoperative group, averaging 56\% (ranging from $0-100 \%$ ), and at 15 days, averaging $14.5 \%$ (ranging from $0-52 \%$ ), at 30 days, averaging $13 \%$ (ranging from $0-32 \%$ ), and at 90 days, averaging $3 \%$ (ranging from 0-28\%), with no statistical significance noted at six months following surgery, averaging 16.5\%. (Table 5) The maximum percentage found at six months following surgery was $29 \%$.

The comparison of the VAS for pain in the LL showed significance between the preoperative group, averaging 64\% (ranging from 7-100\%) and the 15 days group, averaging 16\% (ranging from $0-53 \%$ ), the

Table 1. Evolution of the ODI.

\begin{tabular}{c|c|c|c|c|c}
\hline & \multicolumn{5}{|c}{ Evolution of the ODI } \\
\hline & $\mathbf{2}$ & $\mathbf{3}$ & $\mathbf{4}$ & $\mathbf{5}$ & $\mathbf{6}$ \\
\hline & $\begin{array}{c}\text { Oswestry } \\
\text { pre }\end{array}$ & $\begin{array}{c}\text { oswestry } \\
\mathbf{1 4} \text { days } \\
\text { post }\end{array}$ & $\begin{array}{c}\text { Oswestry } \\
\mathbf{3 0} \text { days } \\
\text { post }\end{array}$ & $\begin{array}{c}\text { Oswestry } \\
\mathbf{3} \text { months }\end{array}$ & $\begin{array}{c}\text { Oswestry } \\
\mathbf{6} \text { months }\end{array}$ \\
\hline Sample size $=$ & 15 & 15 & 11 & 8 & 6 \\
\hline Minimum & 0.1500 & 0.0000 & 0.0800 & 0.0000 & 0.0800 \\
\hline Maximum & 1.0000 & 0.6000 & 0.4600 & 0.3000 & 0.2200 \\
\hline Total Amplitude & 0.8500 & 0.6000 & 0.3800 & 0.3000 & 0.1400 \\
\hline Median & 0.4600 & 0.2800 & 0.2800 & 0.1350 & 0.1450 \\
\hline First quartile (25\%) & 0.3300 & 0.1900 & 0.1650 & 0.0800 & 0.0950 \\
\hline Third quartile (75\%) & 0.6900 & 0.4200 & 0.3360 & 0.2300 & 0.1575 \\
\hline $\begin{array}{c}\text { Interquartile } \\
\text { Deviation }\end{array}$ & 0.5600 & 0.2300 & 0.1700 & 0.1500 & 0.0625 \\
\hline Arithmetic mean & 0.5393 & 0.3045 & 0.2655 & 0.1513 & 0.1383 \\
\hline Variance & 0.0793 & 0.0260 & 0.0154 & 0.0104 & 0.0028 \\
\hline Standard deviation & 0.2817 & 0.1613 & 0.1243 & 0.1019 & 0.0531 \\
\hline Standard error & 0.0727 & 0.0416 & 0.0375 & 0.0360 & 0.217 \\
\hline Coefficient of \\
variation & $52.23 \%$ & $52.96 \%$ & $46.80 \%$ & $67.37 \%$ & $38.37 \%$ \\
\hline Asymmetry (g1) & 0.5314 & 0.2141 & 0.1126 & 0.1239 & 0.3200 \\
\hline Kurtosis (g2) & -0.8233 & -0.2796 & -0.8920 & -0.9965 & -0.2610 \\
\hline Harmonic mean $=$ & 0.3988 & 0.2749 & 0.2022 & 0.1353 & 0.1210 \\
\hline N (harmonic mean) $=$ & 15 & 14 & 11 & 7 & 6 \\
\hline Geometric mean $=$ & 0.4683 & 0.2990 & 0.2350 & 0.1532 & 0.1296 \\
\hline $\begin{array}{c}\mathrm{N} \\
\text { (geometric mean) }=\end{array}$ & 15 & 14 & 11 & 7 & 6 \\
\hline Variance (geom) $=$ & 1.1536 & 1.0848 & 1.1413 & 11.364 & 1.0736 \\
\hline $\begin{array}{c}\text { Standard deviation } \\
\text { (geom) }=\end{array}$ & 1.7745 & 1.5419 & 1.7363 & 1.7205 & 1.4982 \\
\hline & & & & & \\
\hline
\end{tabular}


three month group, averaging 4\% (ranging from 0-60\%), and the six month group, averaging 6\%, (Table 6), with a maximum level of pain of $14 \%$ reported at six months following surgery.

As regards the questions asked 15 days following surgery, $60 \%$ of the patients answered yes to question 1,93.3\% answered yes to question 2, 100\% answered yes to question 3, and 33.3\% answered yes to question 4.

At 30 days following surgery, $60 \%$ answered yes to question 1 , 93.3\% answered yes to question 2, 100\% answered yes to question 3, and $53.3 \%$ answered yes to question 4 .

Having completed three months since surgery, $46.6 \%$ of the patients answered yes to question 1,100\% answered yes to questions 2 and 3 , and $46.6 \%$ answered yes to question 4 .

At the six month postoperative follow-up, $60 \%$ of the patients answered yes to question 1, 1005 answered yes to questions 2 and 3 , and $60 \%$ answered yes to question 4 .

Table 2. Evolution of axial VAS.

\begin{tabular}{c|c|c|c|c|c}
\hline & \multicolumn{5}{|c}{ Evolution of axial VAS } \\
\hline & $\mathbf{7}$ & $\mathbf{9}$ & $\mathbf{1 1}$ & $\mathbf{1 3}$ & $\mathbf{1 5}$ \\
\hline & $\begin{array}{c}\text { Axial } \\
\text { VAS } \\
\text { pre }\end{array}$ & $\begin{array}{c}\text { Axial } \\
\text { VAS } \\
\mathbf{1 5} \text { days }\end{array}$ & $\begin{array}{c}\text { Axial } \\
\text { VAS } \\
\mathbf{3 0} \text { days }\end{array}$ & $\begin{array}{c}\text { Axial } \\
\text { VAS } \\
\mathbf{3} \\
\text { months }\end{array}$ & $\begin{array}{c}\text { Axial } \\
\text { VAS } \\
\mathbf{6} \\
\text { months }\end{array}$ \\
\hline Sample size $=$ & 15 & 12 & 9 & 8 & 6 \\
\hline Minimum & 0.0000 & 0.0000 & 0.0000 & 0.0000 & 0.0000 \\
\hline Maximum & 1.0000 & 0.5200 & 0.3200 & 0.2800 & 0.2900 \\
\hline Total Amplitude & 1.0000 & 0.5200 & 0.3200 & 0.2800 & 2900 \\
\hline Median & 0.5600 & 0.1450 & 0.1300 & 0.0350 & 0.1650 \\
\hline First quartile (25\%) & 0.2900 & 0.0075 & 0.0800 & 0.0000 & 0.1450 \\
\hline Third quartile (75\%) & 0.6950 & 0.2225 & 0.1700 & 0.2400 & 0.2450 \\
\hline Interquartile Deviation & 0.4050 & 0.2150 & 0.0900 & 0.2400 & 0.1000 \\
\hline Arithmetic mean & 0.5207 & 0.1583 & 0.1333 & 0.1063 & 0.1717 \\
\hline Variance & 0.0954 & 0.0240 & 0.0089 & 0.0166 & 0.0109 \\
\hline Standard deviation & 0.3089 & 0.1549 & 0.0942 & 0.1289 & 0.1042 \\
\hline Standard error & 0.0798 & 0.0447 & 0.0314 & 0.0456 & 0.0425 \\
\hline Coefficient of variation & $59.34 \%$ & $97.84 \%$ & $70.66 \%$ & $121.36 \%$ & $60.70 \%$ \\
\hline Asymmetry (g1) & -0.1118 & 1.0605 & 0.5987 & 0.6396 & -0.6589 \\
\hline Kurtosis(g2) & -0.7202 & 1.4391 & 1.0890 & -2.0471 & 0.6336 \\
\hline Harmonic mean $=$ & 0.3309 & 0.0637 & 0.0974 & 0.0715 & 0.1892 \\
\hline $\mathrm{N}$ (harmonic mean) $=$ & 14 & 9 & 8 & 5 & 5 \\
\hline Geometric mean $=$ & 0.4624 & 0.1510 & 0.1258 & 0.1158 & 0.1972 \\
\hline $\mathrm{N}$ (geometric mean) $=$ & 14 & 9 & 8 & 5 & 5 \\
\hline Variance (geom) $=$ & 1.2671 & 1.7103 & 1.2368 & 1.7063 & 1.0479 \\
\hline Standard deviation & 2.0923 & 3.0392 & 2.0128 & 3.0319 & 1.3883 \\
\hline (geom) $=$ & & & & &
\end{tabular}

Only one patient had a recurrence (6.6\%) and had to undergo a second operation. Another patient (6.6\%) suffered an intraoperative dural sac lesion and was treated conservatively (lying down with no head elevation during three days, rest, and analgesic medications: paracetamol, caffeine, and codeine). This patient evolved with regressive headaches for seven days, with complete remission of the symptoms after this period. The first patient to undergo the procedure presented treatment failure and underwent posterior arthrodesis six months following the first surgery.

\section{DISCUSSION}

Full endoscopic discectomy is a relatively recent procedure that is being increasingly more incorporated into the arsenal of therapeutic options, particularly because of its good outcomes reported in the literature by several groups. ${ }^{23-25}$ Ruetten et al., ${ }^{26}$ in their prospective, controlled, randomized study, found similar results between the patients who underwent open microdiscectomy and those who underwent full

Table 4. Comparison of ODI results

\begin{tabular}{|c|c|c|c|c|}
\hline & \multicolumn{4}{|c|}{ Comparison of ODI } \\
\hline & Results & & & \\
\hline $\mathrm{H}=$ & $23 ; 0717$ & & & \\
\hline $\begin{array}{l}\text { DEGREES OF } \\
\text { FREEDOM = }\end{array}$ & 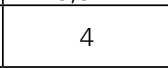 & & & \\
\hline (p) KRUSKAL-WALLIS = & 0.0001 & & & \\
\hline $\mathrm{R} 2=$ & $622 ; 0000$ & & & \\
\hline $\mathrm{R} 3=$ & $446 ; 0000$ & & & \\
\hline R 4 = & $288 ; 0000$ & & & \\
\hline $\mathrm{R} 6=$ & $71 ; 0000$ & & & \\
\hline $\mathrm{R} 5=$ & $113 ; 0000$ & & & \\
\hline R 2 (rank. AVG) = & $41 ; 4667$ & & & \\
\hline R 3 (rank. AVG) $=$ & $29 ; 7333$ & & & \\
\hline R 4 (rank.AVG) = & $26 ; 1818$ & & & \\
\hline R 6 (rank.AVG) = & $11 ; 8333$ & & & \\
\hline $\mathrm{R} 5$ (rank.AVG) $=$ & $14 ; 1250$ & & & \\
\hline $\begin{array}{c}\text { Comparisons } \\
\text { (Dunn method) }\end{array}$ & \begin{tabular}{|c} 
Dif. between \\
ranks
\end{tabular} & $\begin{array}{c}\mathrm{Z} \\
\text { calculated }\end{array}$ & $Z$ critical & $\mathbf{P}$ \\
\hline Rank.AVG 2 and 3 & $11 ; 7333$ & 2;0057 & $2 ; 807$ & ns \\
\hline Rank.AVG 2 and 4 & $15 ; 2848$ & $2 ; 4034$ & $2 ; 807$ & ns \\
\hline Rank.AVG 2 and 6 & $29 ; 6333$ & $3 ; 8292$ & $2 ; 807$ & $<0.05$ \\
\hline Rank.AVG 2 and 5 & $27 ; 3417$ & $3 ; 8982$ & $2 ; 807$ & $<0.05$ \\
\hline Rank.AVG 3 and 4 & $3 ; 5515$ & 0.5584 & $2 ; 807$ & ns \\
\hline Rank.AVG 3 and 6 & $17 ; 9000$ & $2 ; 3130$ & $2 ; 807$ & ns \\
\hline Rank.AVG 3 and 5 & $15 ; 6083$ & $2 ; 2254$ & $2 ; 807$ & ns \\
\hline Rank.AVG 4 and 6 & $14 ; 3485$ & $1 ; 7647$ & $2 ; 807$ & ns \\
\hline Rank.AVG 4 and 5 & $12 ; 0568$ & $1 ; 6196$ & $2 ; 807$ & ns \\
\hline Rank.AVG 6 and 5 & $2 ; 2917$ & 0.2649 & $2 ; 807$ & ns \\
\hline
\end{tabular}

Table 3. Evolution of the radicular pain VAS

\begin{tabular}{|c|c|c|c|c|c|}
\hline & \multicolumn{5}{|c|}{ Evolution of the radicular pain VAS } \\
\hline & 8 & 10 & 12 & 14 & 16 \\
\hline & $\begin{array}{c}\text { Radicular VAS } \\
\text { pre }\end{array}$ & $\begin{array}{c}\text { Radicular VAS } \\
15 \text { days } \\
\end{array}$ & $\begin{array}{c}\text { Radicular VAS } \\
30 \text { days } \\
\end{array}$ & $\begin{array}{c}\text { Radicular VAS } \\
3 \text { months } \\
\end{array}$ & $\begin{array}{c}\text { Radicular VAS } \\
6 \text { months } \\
\end{array}$ \\
\hline Sample size $=$ & 15 & 12 & 9 & 8 & 6 \\
\hline Minimum & 0.0700 & 0.0000 & 0.0000 & 0.0000 & 0.0000 \\
\hline Maximum & 1.0000 & 0.5300 & 1.0000 & 0.6000 & 0.1400 \\
\hline Total Amplitude & 0.9300 & 0.5300 & 1.0000 & 0.6000 & 0.1400 \\
\hline Median & 0.6400 & 0.1600 & 0.1400 & 0.0400 & 0.0600 \\
\hline First quartile $(25 \%)$ & 0.5400 & 0.0000 & 0.1200 & 0.0150 & 0.0000 \\
\hline Third quartile $(75 \%)$ & 0.8600 & 0.3625 & 0.2400 & 0.2400 & 0.1275 \\
\hline Interquartile Deviation & 0.3200 & 0.3625 & 0.1200 & 0.2250 & 0.1275 \\
\hline Arithmetic mean & 0.6507 & 0.2000 & 0.2289 & 0.1500 & 0.0650 \\
\hline Variance & 0.0803 & 0.0349 & 0.0916 & 0.441 & 0.0051 \\
\hline Standard deviation & 0.2834 & 0.1868 & 0.3027 & 0.2103 & 0.0715 \\
\hline Standard error & 0.0732 & 0.0539 & 0.1009 & 0.0744 & 0.0292 \\
\hline Coefficient of variation & $43.55 \%$ & $93.40 \%$ & $132.25 \%$ & $140.20 \%$ & $109.08 \%$ \\
\hline Asymmetry (g1) & -0.8710 & 0.3550 & 2.4982 & 1.6728 & 0.0320 \\
\hline Kurtosis(g2) & 0.4472 & -1.2499 & 6.8929 & 2.6121 & -3.2424 \\
\hline Harmonic mean $=$ & 0.3496 & 0.2337 & 0.1831 & 0.0531 & 0.1295 \\
\hline $\mathrm{N}$ (harmonic mean) $=$ & 15 & 8 & 7 & 6 & 3 \\
\hline Geometric mean $=$ & 0.5388 & 0.2667 & 0.2174 & 0.1019 & 0.1297 \\
\hline $\mathrm{N}$ (geometric mean) $=$ & 15 & 8 & 7 & 6 & 3 \\
\hline Variance (geom) = & 1.3136 & 11.360 & 1.2676 & 2.2643 & 1.0026 \\
\hline $\begin{array}{c}\text { Standard deviation } \\
(\text { geom })=\end{array}$ & 22.089 & 1.7191 & 20.937 & 3.9424 & 1.0801 \\
\hline
\end{tabular}


Table 5. Comparison of axial pain VAS.

\begin{tabular}{|c|c|c|c|c|}
\hline & \multicolumn{4}{|c|}{ Comparison of axial pain VAS } \\
\hline & Results & & & \\
\hline $\mathrm{H}=$ & 15.9541 & & & \\
\hline DEGREES OF FREEDOM $=$ & 4 & & & \\
\hline (p) KRUSKAL-WALLIS = & 0.0031 & & & \\
\hline $\mathrm{R} 7=$ & 567.0000 & & & \\
\hline $\mathrm{R} 9=$ & 249.0000 & & & \\
\hline R $11=$ & 179.0000 & & & \\
\hline $\mathrm{R} 13=$ & 138.0000 & & & \\
\hline $\mathrm{R} 15=$ & 142.0000 & & & \\
\hline R 7 (rank.AVG) $=$ & 37.0000 & & & \\
\hline $\mathrm{R} 9($ rank.AVG $)=$ & 20.7500 & & & \\
\hline R 11 (rank.AVG) $=$ & 19.8889 & & & \\
\hline R 13 (rank.AVG) = & 17.2500 & & & \\
\hline R 15 (rank.AVG) = & 23.6667 & & & \\
\hline $\begin{array}{l}\text { Comparisons } \\
\text { (Dunn method) }\end{array}$ & $\begin{array}{c}\text { Difference } \\
\text { between Posts }\end{array}$ & \begin{tabular}{c|c|}
$\mathbf{Z}$ \\
Calculated
\end{tabular} & $\begin{array}{c}\mathbf{Z} \\
\text { Critical } \\
\end{array}$ & $\mathbf{P}$ \\
\hline Rank.AVG 7 and 9 & 17.0500 & 3.0199 & 2.807 & $<0.05$ \\
\hline Rank.AVG 7 and 11 & 17.9111 & 2.9141 & 2.807 & $<0.05$ \\
\hline Rank.AVG 7 and 13 & 20.5500 & 3.2200 & 2.807 & $<0.05$ \\
\hline Rank.AVG 7 and 15 & 14.1333 & 2.0071 & 2.807 & ns \\
\hline Rank.AVG 9 and 11 & 0.8611 & 0.1340 & 2.807 & ns \\
\hline Rank.AVG 9 and 13 & 3.5000 & 0.5260 & 2.807 & ns \\
\hline Rank.AVG 9 and 15 & 2.9167 & 0.4002 & 2.807 & ns \\
\hline Rank.AVG 11 and 13 & 2.6389 & 0.3725 & 2.807 & ns \\
\hline Rank.AVG 11 and 15 & 3.7778 & 0.4917 & 2.807 & $\mathrm{~ns}$ \\
\hline Rank.AVG 13 and 15 & 6.4167 & 0.8151 & 2.807 & ns \\
\hline
\end{tabular}

endoscopic discectomy, with the same rates of recurrence (6.2\%). FE had a lower index of axial pain after two years of follow-up.

In our study, the patients had good functional outcomes with significant improvement of sciatic pain, in addition to personal satisfaction with the results of their surgeries.

A direct amplified view increases safety during surgical decompression. Full endoscopic discectomy ensures this view due to good illumination and the optics with a $25^{\circ}$ angle. One theoretical advantage is its lower incidence of lesions of the bone structures and the yellow ligament. This, added to the lower incidence of injury to the spinal musculature, reduces local instability and, theoretically, the rate of postoperative complications. It also reduces the rate of epidural fibrosis. ${ }^{26}$
Table 6. Comparison of LL pain VAS.

\begin{tabular}{|c|c|c|c|c|}
\hline & \multicolumn{4}{|c|}{ Comparison of LL VAS. } \\
\hline & Results & & & \\
\hline $\mathrm{H}=$ & $20 ; 4783$ & & & \\
\hline DEGREE OF FREEDOM = & 4 & & & \\
\hline (p) KRUSKAL - WALLIS = & 0,0004 & & & \\
\hline $\mathrm{R} 8=$ & $587 ; 0000$ & & & \\
\hline $\mathrm{R} 10=$ & $256 ; 5000$ & & & \\
\hline $\mathrm{R} 12=$ & $204 ; 0000$ & & & \\
\hline $\mathrm{R} 14=$ & $147 ; 0000$ & & & \\
\hline $\mathrm{R} 16=$ & $80 ; 5000$ & & & \\
\hline R 8 (rank.AVG) = & $39 ; 1333$ & & & \\
\hline R 10 (rank.AVG) = & $21 ; 3750$ & & & \\
\hline R 12 (rank.AVG) = & $22 ; 6667$ & & & \\
\hline R 14 (rank.AVG) = & $18 ; 3750$ & & & \\
\hline R 16 (rank.AVG) = & $23 ; 6667$ & & & \\
\hline $\begin{array}{l}\text { Comparisons } \\
\text { (Dunn method) }\end{array}$ & $\begin{array}{c}\text { Difference } \\
\text { between Posts }\end{array}$ & $\begin{array}{c}\mathbf{Z} \\
\text { Calculated } \\
\end{array}$ & $\begin{array}{c}\mathbf{Z} \\
\text { Critical } \\
\end{array}$ & $\mathbf{P}$ \\
\hline Rank.AVG 8 and 10 & $17 ; 7583$ & $3 ; 1454$ & $2 ; 807$ & $<0.05$ \\
\hline Rank.AVG 8 and 12 & $16 ; 4667$ & $2 ; 6791$ & $2 ; 807$ & Ns \\
\hline Rank.AVG 8 and 14 & $20 ; 7583$ & $3 ; 2527$ & $2 ; 807$ & $<0.05$ \\
\hline Rank.AVG 8 and 16 & $25 ; 7167$ & 36,521 & $2 ; 807$ & $<0.05$ \\
\hline Rank.AVG 10 and 12 & $1 ; 2917$ & 0,2009 & $2 ; 807$ & ns \\
\hline Rank.AVG 10 and 14 & $3 ; 0000$ & 0,4509 & $2 ; 807$ & ns \\
\hline Rank.AVG 10 and 16 & $7 ; 9583$ & $1 ; 0919$ & $2 ; 807$ & ns \\
\hline Rank.AVG 12 and 13 & $4 ; 2917$ & 0,6059 & $2 ; 807$ & ns \\
\hline Rank.AVG 12 and 16 & $9 ; 2500$ & $1 ; 2040$ & $2 ; 807$ & ns \\
\hline Rank.AVG 14 and 16 & $4 ; 9583$ & 0,6298 & $2 ; 807$ & ns \\
\hline
\end{tabular}

\section{CONCLUSION}

The long learning curve, requiring observation of more experienced surgeons and courses conducted in vivo and on cadavers, is one of the limitations of this technique. Additionally, in our service this is a high-cost technique. However, it is a procedure that has been shown to be efficient and that should be included as an alternative or a supplement to conventional discectomy.

All the authors declare that there are no potential conflicts of interest regarding this article.

CONTRIBUTIONS OF THE AUTHORS: Each author made significant individual contributions to the development of the manuscript. DFG, AMC, and RLCR were the principle contributors to the writing of the manuscript. DFG performed the surgeries, followed-up on the patients, and gathered the clinical data. TVOC evaluated the data for the statistical analysis. DFG and AMC conducted the bibliographical research. JSL and MAPA reviewed the manuscript and contributed to the intellectual concept of the study.

\section{REFERENCES}

1. MixterWJ, Barr JS. Rupture of the intervertebral disc with involvement of the spinal canal. N Engl J Med 1934:211:205-10.

2. CasparW. A new surgical procedure for lumbar disc herniation causing less tissue damaging through a microsurgical approach. In: Wü Ilenweber R, Brock M, eds. Advances in neurosurgery; 1977. p. 74-7.

3. Gottlob C, Kopchok GE, Peng SK, Tabbara M, Cavaye D, White RA. Holmium:YAG laser ablation of human intervertebral disc: preliminary evaluation. Lasers Surg Med. 1992:12(1):86-91

4. Hijikata S. Percutaneous dicectomy: a new treatment method for lumbar disc herniation. JToden Hosp. 1975;5:5-13.

5. Kambin $P$, Gellman H. Percutaneous lateral discectomy of the lumbar spine: a preliminary report. Clin Orthop Relat Res. 1983;(174):127-32

6. Maroon JC, Onik G, Sternau L. Percutaneous automated discectomy. A new approach to lumbar surgery. Clin Orthop Relat Res. 1989;(238):64-70.

7. Smith L, Garvin PJ, Gesler RM, Jennings RB. Enzyme dissolution of the nucleus pulposus. Nature. 1963;198:1311-2.

8. Goald HJ. Microlumbar discectomy: followup of 147 patients. Spine (Phila Pa 1976). 1978;3(2):183-5.

9. Nakagawa H, Kamimura M, Uchiyama S, Takahara K, ItsuboT, Miyasaka T. Microendoscopic discectomy (MED) for lumbar disc prolapse. J Clin Neurosci. 2003;10(2):231-5.

10. Perez-Cruet MJ, Foley KT, Isaacs RE, Rice-Wyllie L, Wellington R, Smith MM, et al. Microendoscopic lumbar discectomy: technical note. Neurosurgery. 2002:51(5 Suppl):S129-36.

11. Schick U, Döhnert J, Richter A, König A, Vitzthum HE. Microendoscopic lumbar discectomy versus open surgery: an intraoperative EMG study. Eur Spine J. 2002;11(1):20-6.

12. Ruetten $S$, Komp M, Godolias G. An extreme lateral access for the surgery of lumbar disc herniations inside the spinal canal using the full-endoscopic uniportal transforaminal approachtechnique and prospective results of 463 patients. Spine (Phila Pa 1976). 2005:30(22):2570-8.

13. Ruetten S, Komp M, Godolias G. A New full-endoscopic technique for the interlaminar operation of lumbar disc herniations using 6-mm endoscopes: prospective 2-year results of 331 patients. Minim Invasive Neurosurg. 2006;49(2):80-7.
14. Ruetten S, Komp M, Godolias G. Full-endoscopic interlaminar operation oflumbar disc herniations using new endoscopes and instruments. Orthop Práxis. 2005:10:527-32.

15. Ruetten S. The full-endoscopic interlaminar approach for lumbar disc herniations. In: Mayer HM, editor. Minimally invasive spine surgery. New York: Springer; 2005. p. 346-55.

16. Ebeling U, ReichenbergW, Reulen HJ. Results of microsurgical lumbar discectomy. Review on 485 patients. Acta Neurochir (Wien). 1986:81(1-2):45-52.

17. Ferrer E, García-Bach M, López L, Isamat F. Lumbar microdiscectomy: analysis of 100 consecutive cases. Its pitfalls and final results. Acta Neurochir Suppl (Wien). 1988;43:39-43.

18. Kambin P. Casey K, O'Brien E, Zhou L. Transforaminal arthroscopic decompression of latera recess stenosis. J Neurosurg. 1996:84(3):462-7.

19. Kambin P, O'Brien E, Zhou L, Schaffer JL. Arthroscopic microdiscectomy and selective fragmentectomy. Clin Orthop Relat Res. 1998;(347):150-67.

20. Kambin P, Sampson S. Posterolateral percutaneous suction-excision of herniated lumbar intervertebral discs. Report of interim results. Clin Orthop Relat Res. 1986:(207):37-43.

21. Kambin P, Zhou L. History and current status of percutaneous arthroscopic disc surgery. Spine (Phila Pa 1976). 1996;21(Suppl 24):57S-61S.

22. Kambin P. Arthroscopic microdiscectomy. Baltimore: Urban \& Schwarzenberg; 1991.

23. Ahn Y, Lee SH, Park WM, Lee HY, Shin SW, Kang HY. Percutaneous endoscopic lumbar discectomy for recurrent disc herniation: surgical technique, outcome, and prognostic factors of 43 consecutive cases. Spine (Phila Pa 1976). 2004;29(16):E326-32.

24. Lee SH, Kim SK, Ahn Y. The preoperative radiological findings that affect the clinical outcomes after percutaneous endoscopic lumbar discectomy. Word Spine J. 2006:1:133-40.

25. Ruetten S, Komp M, Merk H, Godolias G. Full-endoscopic interlaminar and transforaminal lumbar discectomy versus conventional microsurgical technique: a prospective, randomized, controlled study. Spine (Phila Pa 1976). 2008:33(9):931-9.

26. Ruetten S, Meyer O, Godolias G. Epiduroscopic diagnosis and treatment of epidural adhesions in chronic back pain syndrome of patients with previous surgical treatment: first results of 31 interventions. Z Orthop Ihre Grenzgeb. 2002;140(2):171-5 